\title{
Analysis of polycyclic aromatic hydrocarbons in fish: Optimisation and validation of microwave-assisted extraction
}

\author{
Maria João Ramalhosa, Paula Paíga, Simone Morais, Ana M.M. Sousa, Maria P. Gonçalves, \\ Cristina Delerue-Matos, Maria Beatriz Prior Pinto Oliveira
}

\begin{abstract}

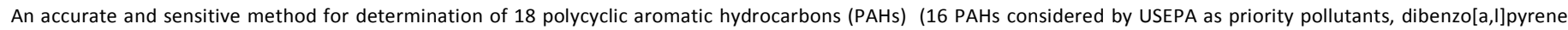

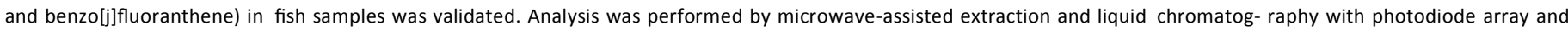

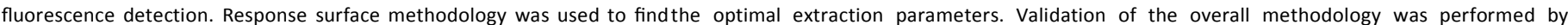

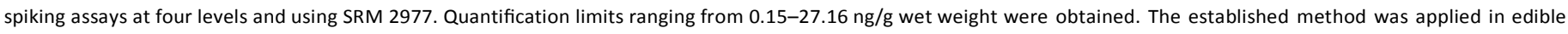

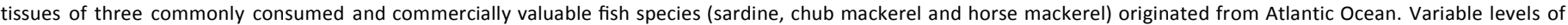

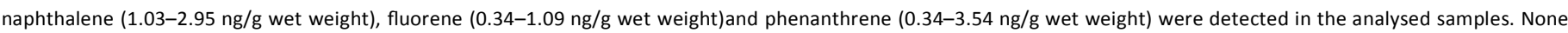
of the sam-ples contained detectable amounts of benzo[a]pyrene, the marker used for evaluating the occurrence and carcinogenic effects of PAHs in food.
\end{abstract}

\section{Introduction}

Polycyclic aromatic hydrocarbons (PAHs) are environmental contaminants with the majority coming from anthropogenic activ-ities (WHO, 1998). The health concerns of PAHs are due to their po- tential cytotoxicity, mutagenicity and carcinogenicity in humans (WHO, 1998). U.S. Environmental Protection Agency (USEPA) listed 16 priority PAHs (USEPA, 1986). Excluding smokers and occupa- tionally exposed populations, most individuals are exposed to PAHs predominantly from dietary sources. Consequently, since the past decade, PAHs are under evaluation by the International Programme on Chemical Safety (IPCS), the Scientific Committee on Food (SCF) and by the Joint FAO/WHO Expert Committee on Food Additives (JECFA). Benzo[a]pyrene is regarded as a marker for the occurrence and genotoxic and carcinogenic effects of PAHs in food. Maximum levels had been set for diverse categories of food products, including fish and seafood (Commission Regulation, 2006). However, more carcinogenic PAHs, such as dibenzo[a,l]pyr- ene or dibenz[a,h]anthracene were found. Dibenzo[a,l]pyrene, as well as benzo[j]fluoranthene, are not included in the USEPA list but are considered in EC Recommendation 1881/2006 (2006).
Studies that include the determination of dibenzo[a,I]pyrene, and of other EU priority PAHs that are not in USEPA list, in fish matrices are limited (Duedahl-Olesen \& Ghorbani, 2008; Ramalhosa, Paíga, Morais, DelerueMatos, \& Oliveira, 2009; Serpe, Esposito, Gallo, \& Serpe, 2010).

Rising incomes, the ensuing diversification of diets and fish nutritional benefits related to its proteins of high biological quality as well as desirable lipid composition (rich in essential x-3 polyun-

saturated fatty acids) are leading to a shift towards significantly higher fish consumption in developing countries. World apparent per capita finfish and seafood consumption has steadily increasing from an average of 9.9 $\mathrm{kg}$ in the 1960s reaching $16.4 \mathrm{~kg}$ in 2005 (FAO, 2009). Portuguese annual consumption of fish is $55.6 \mathrm{~kg}$ per capita year $^{-1}$, being Portugal the largest consumer among all of the EU countries (European Commission, 2010) and one of the biggest in the world. Sardine (Sardina pilchardus), chub mackerel (Scomber japonicus) and horse mackerel (Trachurus trachurus) rep- resent some of the most important pelagic fish groups captured; chub mackerel was the sixth species that contributed most to glo- bal catches in 2006 (FAO, 2009). In Portugal, they represent the three most consumed fish species (sardine > chub mackerel $>$ horse mackerel) (European Commission, 2010).

A large number of studies have been published on extraction of PAHs from fish, being a limiting step in the quantitative analysis. 
Several authors have compared a range of extraction techniques, such as Soxhlet extraction (Janska, Tomaniova, Hajslova, \& Koco- urek, 2006), ultrasonic extraction (Janska et al., 2006), supercritical fluid extraction, pressurised liquid extraction (Duedahl-Olesen \& Ghorbani, 2008), matrix solid-phase dispersion (Pensado, Casais, Mejuto, \& Cela, 2005) and microwave-assisted extraction (MAE) (Akpambang et al., 2009; El-Saeid, 2006; Pena et al., 2006; Soclo, Budzinski, Garrigues, \& Matsuzawa, 2008). The ability to rapidly heat the sample-solvent mixture is inherent to MAE and the main advantage of this technique. By using closed vessels, the extraction can be performed at elevated temperatures accelerating the mass transfer of target compounds from the sample matrix. In most cases, reproducibility and extraction yields are improved com- pared to those reached by traditional methods, using less energy and solvent volume (Sousa, Alves, Morais, Delerue-Matos, \& Gonç- alves, 2010). No work was found concerning simultaneous and quantitative MAE of the 16 PAHs considered by USEPA as priority pollutants, dibenzo[a,I]pyrene and benzo[j]fluoranthene from fatty fish samples.

Considering that PAHs are among the most health-relevant contaminants in fish, this work aims to optimise and validate an accurate and sensitive method for the determination of PAHs in fish samples. The developed work included the simultaneous analysis of 18 PAHs (the 16 PAHs considered by USEPA as priority pollutants, dibenzo[a,I]pyrene and benzo[j]fluoranthene corre- sponding to $10 \mathrm{PAHs}$ included in EC Recommendation 1881/ 2006 by MAE and liquid chromatography (LC) with fluorescence detection (FLD). The influence of the MAE operational parameters on PAHs recovery was evaluated by response surface methodol- ogy(RSM).

The validated method was applied to determine the presence of the selected PAHs in sardine, chub and horse mackerel. There is quite limited information on PAH concentrations in edible tissues of these three commonly consumed and commercially highly valu- able fish species originated from Atlantic Ocean (Llobet, Falcó, Bo- cio, \& Domingo, 2006; Perelló, Marti-Cid, Castell, Llobet, \& Domingo, 2009; Ramalhosa et al., 2009).

\section{Experimental}

\subsection{Reagents and materials}

Certified EPA 610 Polynuclear Aromatic Hidrocarbons standard mixture containing naphthalene $\left(Y_{1}\right) 1000 \mathrm{Ig} / \mathrm{mL}$, acenaphthylene $\left(Y_{2}\right) 2000 \mathrm{Ig} / \mathrm{mL}$, acenaphthene $\left(Y_{3}\right) 1000 \mathrm{Ig} / \mathrm{mL}$, fluorene $\left(Y_{4}\right)$

$199.9 \mathrm{Ig} / \mathrm{mL}$, phenanthrene $\left(Y_{5}\right) 99.8 \mathrm{Ig} / \mathrm{mL}$, anthracene $\left(Y_{6}\right)$

$100.0 \mathrm{Ig} / \mathrm{mL}$, fluoranthene $\left(Y_{7}\right) 200.1 \mathrm{Ig} / \mathrm{mL}$, pyrene $\left(Y_{8}\right) 99.9 \mathrm{Ig} / \mathrm{mL}$, benz[a]anthracene $\left(Y_{9}\right) 100.1 \mathrm{Ig} / \mathrm{mL}$, chrysene $\left(Y_{10}\right) 100.0 \mathrm{Ig} / \mathrm{mL}$, benzo[b]fluoranthene $\left(Y_{11}\right) 200.2 \mathrm{Ig} / \mathrm{mL}$, benzo[k]fluoranth- ene $\left(Y_{13}\right)$ $99.9 \mathrm{Ig} / \mathrm{mL}$, benzo[a]pyrene $\quad\left(Y_{14}\right) \quad 100.0 \mathrm{Ig} / \mathrm{mL}$ dibenz[a,h]anthracene $\quad\left(Y_{16}\right) \quad 200.0 \mathrm{Ig} / \mathrm{mL}$, benzo[g,h,i]perylene $\left(Y_{17}\right)$ $200.0 \mathrm{Ig} / \mathrm{mL}$ and indeno[1,2,3-cd]pyrene $\left(Y_{18}\right) 100.1 \mathrm{Ig} / \mathrm{mL}$

was provided from Supelco (Bellefonte, PA, USA). Individual stan-

dards of each referred PAHs, benzo[j]fluoranthene $\left(Y_{12}\right)$ and dibenzo[a,I]pyrene $\left(Y_{15}\right)(2000 \mathrm{Ig} / \mathrm{mL})$ were also purchased from

Supelco (Bellefonte, PA, USA). PAH purities were guaranteed be- tween $97.9 \%$ and $99.9 \%$. Working mixed standard solutions con- taining all the PAHs were prepared by dilution of the stock solutions with acetonitrile and stored at $-20{ }^{\circ} \mathrm{C}$ in darkness to avoid volatilisation and photodegradation.

Standard reference material SRM 2977 (Mussel tissue) was sup- plied by NIST (Gaithersburg, ND, USA).

Acetone (Riedel-de Haën, Seelze, Germany, purity 99.8\%), $n$ - hexane (Chromasolv, Merck, Darmstadt, Germany) and acetonitrile (Sigma-Aldrich, Steinheim, Germany, purity $>99.9 \%$ ) were the solvents used. Ultrapure water was produced by a Milli-Q simplic-ity 185 system (Millipore, Molsheim, France).

The glassware was washed with detergent and water, rinsed with acetone and $n$-hexane (Vaz Pereira, Sintra, Portugal) and dried at $90{ }^{\circ} \mathrm{C}$ before use.

\subsection{Sample collection and characterisation}

Fresh samples $(n=88)$ caught in Portuguese waters, from the Northeast (sardine and horse mackerel) and Eastern Central Atlan- tic Ocean (chub mackerel), were purchased randomly from several markets in the Porto Metropolitan area (NW Portugal). The species collected were sardine (30 individuals), horse mackerel ( 28 indi- viduals) and chub mackerel (30 individuals). Specimens were transported to the laboratory in clean polyethylene bags, stored in ice and processed immediately after collection.

Sample collection and biometric characterisation were per- formed in accordance to U.S. EPA Guide No 823-B-00-07 and CE Regulation No. 333/2007 (European Commission, 2007). Speci- mens were manually headed, eviscerated and filleted. Only the edi-ble tissues were preserved. Each sample for further analysis (composite) consisted of an equal amount of the edible parts of, at least, four individuals and had a minimum mass of $200 \mathrm{~g}$. Fish muscles were mechanically homogenised with a kitchen blender(Brio $400 \mathrm{~W}_{\text {MAX }}$ Ufesa, Spain). The homogenised samples were

kept frozen in $125 \mathrm{~mL}$ polycarbonate containers at $-20^{\circ} \mathrm{C}$ until analysis (Ramalhosa et al., 2009).

Moisture was evaluated using $10 \mathrm{~g}$ of homogenised sample according to the Portuguese Standard NP 2282-1991 and the offi- cial AOAC method (AOAC, 2007). For total fat content determina- tion, the recommended AOAC method (AOAC, 2007) was applied.

\subsection{Liquid chromatography analysis}

Extracts were analysed using a Shimadzu LC system (Shimadzu Corporation, Kyoto, Japan) equipped with a LC-20AB pump (high- pressure gradient solvent delivery module equipped with two dual-plunger tandem-flow pumps), DGU-20AS degasser and photo- diode array SPDM20A (PAD) and fluorescence RF-10AXL (FLD) detectors on line. Separation of the compounds was performed in a C18 column (CC 150/4 Nucleosil 100-5 C18 PAH, $150 \times 4.0 \mathrm{~mm}$;

$5 \mathrm{Im}$ particle size; Macherey-Nagel, Duren, Germany) maintained at room temperature $\left(20 \pm 1^{\circ} \mathrm{C}\right)$. The injected volume was $15 \mathrm{IL}$. The initial

composition of the mobile phase was $50 \%$ of acetoni-

trile and $50 \%$ water and a linear gradient to $100 \%$ was programmed in 15 $\mathrm{min}$, with a final hold of $13 \mathrm{~min}$. Initial conditions were reached in 1 $\min$ and maintained for $6 \mathrm{~min}$ before next run. The to- tal run time was 40 min with a flow rate of $0.8 \mathrm{~mL} / \mathrm{min}$ (Ramalhosa et al., 2009).

Fluorescence wavelength programming was used to perform better sensitivity and minimal interference. Each compound wasdetected at its optimum excitation/emission wavelength pair:260/315 nm (naphthalene, acenaphthene and fluorene), 260/366 nm (phenanthrene), 260/430 nm (anthracene, fluoranthene, pyrene, benz[a]anthracene, crysene, benzo[b + j]fluoranthene, benzo[k]fluoranthene, benzo[a]pyrene, dibenz[a,h]anthracene, benzo[g,h,i]perylene and dibenzo[a,l]pyrene,) and 290/505 nm (in- deno[1,2,3-cd]pyrene). Acenaphthylene, which shows limited fluo-rescence, was analysed at $254 \mathrm{~nm}$ in PAD.

External calibrations with PAH mixed matrix matched stan- dards (i.e. standards prepared with blank fish extracts obtained using the optimum MAE conditions and acetonitrile), using six cal- ibration points, were performed (Ramalhosa et al., 2009). Each analysis was run at least in triplicate. 
Table 1

PAH recoveries (mean \pm relative standard deviation; $n=6$ ) from spiked homogenised sardine samples and NIST reference material SRM 2977 using the optimal microwave extraction conditions.

\begin{tabular}{|c|c|c|c|c|c|c|c|c|c|c|c|c|}
\hline \multirow[t]{3}{*}{ Compound } & \multicolumn{9}{|c|}{ Spiking assays } & \multicolumn{3}{|l|}{ SRM 2977} \\
\hline & \multicolumn{4}{|c|}{$\begin{array}{l}\text { Spiking level (ng/g wet } \\
\text { weight) }\end{array}$} & \multicolumn{5}{|c|}{ Recovery \pm RSD (\%) } & \multicolumn{2}{|c|}{$\begin{array}{l}\text { Mass fraction, mean } \pm S D \quad(n g / g \text { wet } \\
\text { weight) }\end{array}$} & \multirow[t]{2}{*}{$\begin{array}{l}\text { Recovery } \pm \text { RSD } \\
\text { (\%) }\end{array}$} \\
\hline & I & $\|$ & III & IV & । & $\|$ & III & & IV & $\begin{array}{l}{ }^{\mathrm{a}} \text { Certified or } \\
{ }^{\mathrm{b}} \text { Reference values }\end{array}$ & $\begin{array}{l}\text { Measured } \\
\text { values }\end{array}$ & \\
\hline Naphthalene, $Y_{1}$ & 200.0 & 100.3 & 50.2 & 19.1 & $91.1 \pm 3.2$ & $90.0 \pm 2.3$ & $89.6 \pm 0.7 \quad \varepsilon$ & $89.7 \pm$ & \pm 1.0 & $19 \pm 5^{b}$ & n.q. ${ }^{\mathrm{c}}$ & n.q. ${ }^{c}$ \\
\hline Acenaphthylene, $Y_{2}$ & 549.6 & 350.2 & 175.1 & 126.0 & $91.8 \pm 2.6$ & $90.7 \pm 4.5$ & $96.0 \pm 7.3$ & $95.1 \pm$ & \pm 3.0 & - & - & - \\
\hline Acenaphthene, $Y_{3}$ & 200.0 & 100.3 & 50.2 & $\quad 19.1$ & $96.4 \pm 1.6$ & $99.8 \pm 5.2$ & $82.0 \pm 2$ & & $79.8 \pm 8.5$ & $4.2 \pm 0.4^{b}$ & $3.05 \pm 0.12$ & $72.5 \pm 3.9$ \\
\hline Fluorene, $Y_{4}$ & 39.5 & 19.8 & 9.9 & 3.8 & $89.3 \pm 1.5$ & $84.4 \pm 3.0$ & $84.6 \pm 4$ & & $72.2 \pm 4.8$ & $10.24 \pm 0.43^{b}$ & $5.99 \pm 0.30$ & $58.5 \pm 5.0$ \\
\hline Phenanthrene, $Y_{5}$ & 20.0 & 10.0 & 5.0 & 1.9 & $71.4 \pm 5.2$ & $66.8 \pm 2.8$ & $72.9 \pm 5$ & & $65.0 \pm 3.0$ & $35.1 \pm 3.8^{\mathrm{b}}$ & $33.2 \pm 0.9$ & $94.7 \pm 2.6$ \\
\hline Anthracene, $Y_{6}$ & 20.0 & 10.0 & 5.0 & 1.9 & $84.9 \pm 3.5$ & $83.7 \pm 2.7$ & $83.8 \pm 1$ & & $79.1 \pm 3.0$ & $8 \pm 4^{b}$ & $5.0 \pm 0.3$ & $62.6 \pm 6.4$ \\
\hline Fluoranthene, $Y_{7}$ & 39.3 & 19.7 & 9.9 & 3.8 & $97.2 \pm 3.2$ & $97.9 \pm 3.0$ & $97.3 \pm 0$. & & $93.6 \pm 2.3$ & $38.7 \pm 1.0^{\mathrm{a}}$ & $37.9 \pm 1.0$ & $97.8 \pm 2.7$ \\
\hline Pyrene, $Y_{8}$ & 19.3 & 9.7 & 4.8 & 1.8 & $101.2 \pm 4.2$ & $97.8 \pm 3.7$ & $98.4 \pm 2$ & & $97.0 \pm 2.9$ & $78.9 \pm 3.5^{\mathrm{a}}$ & $47.4 \pm 2.7$ & $60.0 \pm 5.6$ \\
\hline Benz[a]anthracene, $Y_{9}$ & 19.6 & 9.8 & 4.9 & 1.9 & $90.6 \pm 3.1$ & $93.7 \pm 3.5$ & $84.2 \pm 3$ & & $89.7 \pm 2.8$ & $20.34 \pm 0.78^{\mathrm{a}}$ & $12.5 \pm 0.3$ & $61.5 \pm 2.7$ \\
\hline Chrysene, $Y_{10}$ & 19.8 & 9.9 & 5.0 & 1.9 & $86.2 \pm 3.7$ & $86.2 \pm 3.7$ & $83.1 \pm 1$ & & $88.9 \pm 3.2$ & $49 \pm 2^{\mathrm{b}}$ & n.q. ${ }^{c}$ & n.q. ${ }^{c}$ \\
\hline $\begin{array}{l}\text { Benzo[b }+j] \text { fluoranthene, } \\
\quad Y_{11,12}\end{array}$ & 80.0 & 40.1 & 20.0 & 7.6 & $81.3 \pm 5.1$ & $82.5 \pm 4.3$ & $79.8 \pm 1$ & & $75.5 \pm 2.4$ & $15.61 \pm 0.28^{b}$ & $14.59 \pm 0.46$ & $93.5 \pm 3.1$ \\
\hline Benzo[k]fluoranthene, $Y_{13}$ & 19.9 & 10.0 & 5.0 & 1.9 & $80.4 \pm 3.9$ & $84.2 \pm 4.1$ & $80.4 \pm 2.3$ & $84.0 \pm$ & \pm 2.6 & $4 \pm 1^{b}$ & $3.99 \pm 0.02$ & $99.7 \pm 0.6$ \\
\hline Benzo[a]pyrene, $Y_{14}$ & 20.0 & 10.0 & 5.0 & 1.9 & $78.0 \pm 3.6$ & $79.0 \pm 5.2$ & $75.4 \pm 2.1$ & $78.0 \pm$ & \pm 1.4 & $8.35 \pm 0.72^{\mathrm{a}}$ & $5.86 \pm 0.10$ & $70.2 \pm 1.2$ \\
\hline Dibenzo[a,l]pyrene, $Y_{15}$ & 40.0 & 20.0 & 10.0 & 3.8 & $73.5 \pm 2.4$ & $70.6 \pm 4.0$ & $64.5 \pm 3.5$ & $67.0 \pm$ & \pm 2.2 & - & - & - \\
\hline $\begin{array}{l}\text { Dibenz }[\mathrm{a}, \mathrm{h}] \text { anthracene, } \\
\qquad Y_{16}\end{array}$ & 39.9 & 20.0 & 10.0 & 3.8 & $81.0 \pm 3.6$ & $79.3 \pm 2.8$ & $79.8 \pm 1.0$ & $74.0 \pm$ & \pm 2.7 & $1.41 \pm 0.19^{\mathrm{a}}$ & $1.21 \pm 0.04$ & $85.8 \pm 3.2$ \\
\hline Benzo[g,h,i]perylene, $Y_{17}$ & 39.7 & 19.9 & 10.0 & 3.8 & $78.2 \pm 1.8$ & $75.1 \pm 2.8$ & $70.2 \pm 4$ & & $73.4 \pm 2.5$ & $9.53 \pm 0.43^{\mathrm{a}}$ & $7.47 \pm 0.45$ & $78.4 \pm 6.0$ \\
\hline $\begin{array}{l}\text { Indeno[1,2,3-cd]pyrene, } \\
\qquad Y_{18}\end{array}$ & 20.0 & 10.0 & 5.0 & 1.9 & $74.2 \pm 5.0$ & $77.7 \pm 2.6$ & $77.7 \pm 0$. & & $76.3 \pm 2.7$ & $4.84 \pm 0.81^{\mathrm{a}}$ & $3.15 \pm 0.14$ & $65.2 \pm 4.5$ \\
\hline
\end{tabular}

${ }^{a}$ certified values.

b reference values.

${ }^{c}$ n.q., not quantified due to peak overlapping.

\subsection{Microwave-assisted extraction}

Microwave-assisted extractions were performed with a MARS-X $1500 \mathrm{~W}$ (Microwave Accelerated Reaction System for Extraction and Digestion, CEM, Mathews, NC, USA) configured with a 14 posi- tion carousel. For recovery assays in the optimisation studies, a homogenised composite of sardine (humidity $50.9 \pm 2.3 \%$ and total fat content of $21.9 \pm 0.5 \%$ ) was used since this species is very rich in fat increasing the difficulty of the extraction process. $0.5 \mathrm{~g}$ of sar- dine sample was fortified with $0.25 \mathrm{~mL}$ of working standard solution containing the 18 selected PAHs at spiking level II (Table 1). Spiked samples were allowed to stand for $30 \mathrm{~min}$ before extraction, pro- tected from light. Spiked and non-spiked (blank) fish samples were transferred to the glass extraction vessels with the tested extraction solvent (acetonitrile or hexane-acetone $(1: 1, v / v))$ and volume; then the vessels were closed. During operation, both temperature and pressure were monitored in a single vessel (control vessel). Magnetic stirring in each extraction vessel and a sensor registering the solvent leaks in the interior of the microwave oven were also utilised.

After MAE, the vessels were allowed to cool at room temperature before opening. The extracts were then carefully filtered through a PTFE membrane filter $(0.45 \mathrm{Im})$ and reduced to a small volume using a rotary evaporator (Buchi Rotavapor, R-200) at $20^{\circ} \mathrm{C}$. Then, a gentle stream of nitrogen was used to evaporate the extracts and immediately before chromatographic analysis, the residue was redissolved in $0.5 \mathrm{~mL}$ of acetonitrile.

\subsection{Statistical analysis}

The optimisation of MAE of PAHs was made using RSM (Mont- gomery, 1991).

All statistical analyses were made using the software Statistica ver- sion 6.0 (StatSoft, Inc., Tulsa, UK), namely, multifactor variance analy- sis (ANOVA) and response surface 3D plots. The two factors not represented by the horizontal axes were fixed at their 0 level values.

Significance of each coefficient present in regression equations of the models as well as, studied factors and their interactions effects was determined by the student's $t$-test and $p$ values (a
95\% confidence level was used). Factors and/or interactions with an experimental error greater than the effect $(p$ value $>0.05)$ were not influential. If the model did not predict a satisfactory solution optimum conditions were obtained by surface 3D plots inspection and based on statistical information. In this study, the main goal was to find the optimum conditions that simultaneously maxi-mised all responses. All experiments were performed in random-ized order to minimise bias effect.

\subsection{Validation procedure}

After MAE optimisation using the spiking level II (Table 1) and RSM, the overall MAE-LC procedure for analysis of PAHs in fish samples was validated by systematic recovery experiments at other three levels (Table 1) and analysing the certified reference material SRM 2977 Mussel tissue.

\section{Results and discussion}

\subsection{Optimisation of microwave-assisted extraction}

\subsubsection{Preliminary considerations}

The main purpose of this study was to develop a simple and ro- bust method based on MAE and LC-FLD for the determination of 18 PAHs in fish samples. The chromatographic programme previously optimised (Ramalhosa et al., 2009) allowed an efficient separation and quantification of the studied compounds in only $40 \mathrm{~min}$ The average retention time, linearity range, detection limit (LOD), quan- tification limit (LOQ) and quadratic correlation coefficients $\left(R^{2}\right)$ for each PAH are presented in Table 4. Calibration curves obtained using six mixed matrix matched standards containing all the PAHs showed good linearity over the entire range of concentrations with quadratic correlation coefficients $\left(R^{2}\right)$ higher than 0.999. LODs and

LOQs were calculated from sardine spiked extracts (Miller \& Miller, 2000). LODs between $0.04 \mathrm{ng} / \mathrm{g}$ wet weight $(0.09 \mathrm{Ig} / \mathrm{L})$ for benzo[k]fluoranthene and $8.15 \mathrm{ng} / \mathrm{g}$ wet weight $(16.30 \mathrm{Ig} / \mathrm{L})$ for acenaphthylene were obtained, with corresponding LOQs in the 
range $0.15-27.16 \mathrm{ng} / \mathrm{g}$ wet weight $(0.30-54.33 \mathrm{Ig} / \mathrm{L})$. Globally, the attained sensitivity is appropriate for PAHs screening and determi- nation in fish samples at low $\mathrm{ng} / \mathrm{g}$ wet weight level. Moreover, it is clearly adequate for analysis of the maximum level of $2 \mathrm{ng} / \mathrm{g}$ wet weight established by Commission Regulation (EC) No. 2006/1881/EC for benzo[a]pyrene (the marker used for the carcinogenic risk of PAHs) in muscle meat of fish in order to minimise the harm- ful effects on human health (Commission Regulation, 2006).

Contrary to previous published studies (Fuoco, Giannarelli, Onor, Ceccarini, \& Carli, 2005; Pena et al., 2006; Serpe et al., 2010; Stolyhwo \& Sikorski, 2005), clean up of MAE extracts was not found to be necessary.

Selection of an appropriate solvent is one of the most important factors in the development of an extraction procedure. The solvent should extract analytes quantitatively from the matrix and should preferentially be compatible with the quantitative procedure used. When considering MAE, due to the principle of microwave heating, the choice of the solvent depends also on its ability to absorb microwaves, defined by its dielectric constant $\left(e^{0}\right)$. Hexane-acetone mixtures, toluene, methylene chloride, benzene, cyclohexane, and dichloromethane are known to be good solvents for PAH extrac- tions and are commonly used worldwide although some are highly toxic and should be slowly being phased out from analytical meth- ods (Maioli, Rodrigues, Knoppers, \& Azevedo, 2010; PortetKoltalo, Oukebdane, Dionnet, \& Desbène, 2008; Selli \& Cayhan, 2009; Serpe et al., 2010; Soclo et al., 2008). Apolar solvents such as hexane do not meet the requirement to can be used in MAE and despite the fact they are known to be appropriate for aromatic compounds they cannot be used alone.

In this study, only solvents that have low toxicity were tested. On the other hand, no work was devoted to find a suitable solvent for the MAE of PAHs from fish samples. The mixture hexane-ace- tone $(1: 1, \mathrm{v} / \mathrm{v})$ was chosen since it is recommended in USEPA Method 3546 (U.S. Environmental Protection Agency, 2000) and it has proven to be an efficient solvent system for the extraction of different pollutants from environmental samples such as PAHs, organochlorine pesticides, PCBs and phenols (U.S Environmental Protection Agency, 2000).

Acetonitrile was also tested since it has an higher dielectric con-

stant than acetone which is commonly used $\left(e^{0} \quad\right.$ acetonitrile $=35.9$, Cacetone $=20.7$ at $25^{\circ} \mathrm{C}$ (Richardi \& Krienke, 1997)). It is compatible with the LC-FLD procedure and consequently no solvent exchange is required reducing the loss of analytes during sample prepara- tion Moreover, none of the previous works related with MAE of PAHs from fish samples tested it as solvent.

In preliminary experiments, the efficiency of PAHs MAE by hex- aneacetone $(1: 1, \mathrm{v} / \mathrm{v})$ and acetonitrile at $90,100,110,120$ and $130{ }^{\circ} \mathrm{C}$ was compared. The other MAE parameters were maintained constant at the following values: $20 \mathrm{~mL}$ of extraction solvent, 20 min of extraction time and medium stirring. On the basis of the results obtained acetonitrile was selected as an appropriate solvent

\subsubsection{Response surface methodology}

Classical optimisation studies use the one-factor-at-a-timeap- proach, which is time-consuming and expensive. In addition, pos- sible interaction effects between variables cannot be evaluated and misleading conclusions may be drawn. RSM was applied in this study since it can overcome these difficulties and allows account- ing for possible interaction effects between variables.

RSM is a collection of mathematical and statistical techniques useful for the modelling and analysis of problems in which a response of interest is influenced by several variables and the objective is to optimise this response or determine the region thatsatisfies the operating specifications (Montgomery, 1991; Sousa et al., 2010). This procedure involves fitting a function to the experimental data and then using optimisation techniques to ob- tain the optimum parameters.

The experimental domain and the selection of solvent were established taking into account the results obtained in preliminary tests and all significant parameters in a typical MAE process were chosen: extraction time $\left(X_{1} ; \mathrm{min}\right)$, temperature $\left(X_{2} ;{ }^{\circ} \mathrm{C}\right)$, solventvolume $\left(X_{3} ; \mathrm{mL}\right)$ and stirring speed $\left(X_{4}\right.$; four positions are available in modern apparatus: turned off, minimum, medium and maxi-mum speed) (Table 2). The optimisation of MAE of PAHs was made using homogenised sardine samples spiked with the standard solu-tion mixture containing the 18 selected PAHs at the spiking level II (Table 1). PAH recoveries were the response variables studied $\left(Y_{1}-Y_{18}\right)$. An orthogonal central composite design with four parameters,

$2^{4}$, was the approach made to the optimisation problem. This design included 36 experiments to estimate the models coefficients:

16 points of a factorial design at levels $a= \pm 1.000$, eight axial points at a distance $a= \pm 2.000$ from the centre, and a centre pointwith 12 replications (Table 2). The 12 replicates at centre point al- lowed estimating experimental error and checking the fit.

PAH recoveries (Table 2) obtained in the first set of runs (runs 1-16 in Table 2) were adjusted to first order models. When the first order models did not reveal a significant lack of fit $(p>0.05)$ steep- est ascent method was applied in order to move more rapidly to optimum vicinity. However the parameter values obtained with this method were impossible to put in practice and so, additional runs were carried out (runs 29-36 in Table 2). Due to experimental limitations, run 36 (the equipment does not have a stirring speed higher than the maximum one) was not performed nor statistically considered by the software and proper cautions were accounted for when defining high/low factor values.

Experimental data were fitted to the following second order model (Montgomery, 1991),

$$
Y_{i}=b_{0}+\sum_{i} b_{l} X_{i}+\sum_{j} b_{i j} X_{i} X_{j}+\sum_{i} b_{i l} X_{i}^{2}+\varepsilon
$$

where $Y_{i}$ is the experimental response, $X_{i}$ are the studied factors, $b_{0}$ is the average response, $b_{i}$ are the average effects of the different factors, $b_{\mathrm{ij}}$ are the average effects of second interaction factors, $b_{\text {ii }}$ are the quadratic components and $e$ is the experimental error. Inor-

der to validate a model, appropriate analysis of variance (ANOVA) must be carried out. The total sum of squares of the mathematical model is divided into the sum of squares due to the regression (SS model in Table 3) and the residual sum of squares (SS residual in Ta- ble 3). The latter, can be divided in two parts: one part due to pure experimental error and is computed as the sum of squared devia- tions (SS pure error in Table 3) in the centre point experiments, and the second part corresponds to the lack of fit (Table 3 ). The fit- ted models are considered adequate if they reach significance ( $p$ va-lue $<0.05$ for a $95 \%$ confidence level) and their lack of fit is not significant ( $p$ value $>0.05$ for the same confidence level).

All second order models reached statistical significance $(p<0.05$; $Y_{1}-Y_{18}$ in Table 3) with exception of indeno[1,2,3,cd]pyr- ene $\left(p>0.05 ; Y_{18}\right.$ in Table 3). As desired, $Y_{3}, Y_{6}, Y_{7}, Y_{10}$ and $Y_{18}$ lacks of fit were not significant $(p>0.05$; Table 3$)$ yet, remain com- pounds showed a persistent lack of fit even after the models expansion $(p<0.05$ in Table 3$)$. This apparent contradiction may be related with the insufficient number of experimental observa- tions that were unable to carry out a more appropriate analysis of the residues because of the high number of parameters involved in the optimisation problem (Montgomery, 1991). In these cases, the application of the steepest ascent method led to operational parameters that could not be successfully employed and so, opti- mum conditions were found by $3 \mathrm{D}$ plots analysis and statistical information. The second order model quadratic correlation coeffi- cients ( $R^{2}$ in Table 3) of $Y_{1}, Y_{4-7}$ and $Y_{11-15}$ were clearly above or in the minimum limit considered acceptable for data of chemical 
Table 2

Real values, coded levels and observed responses (PAH recoveries, \%) for the experimental design $2^{4}\left(X_{1}-\right.$ extraction time (min); $X_{2}-$ temperature $\left({ }^{\circ} \mathrm{C}\right) ; X_{3}-$ solvent volume (mL); $\left.X_{4}-s t i r r i n g ~ s p e e d\right)$. Fortification level II (defined in Table

1) was used for MAE optimisation using RSM.

\begin{tabular}{|c|c|c|c|c|c|c|c|c|c|c|c|c|c|c|c|c|c|c|c|c|c|}
\hline \multirow[t]{2}{*}{ Run } & \multicolumn{3}{|c|}{ MAE parameters } & \multirow[b]{2}{*}{$x_{4}$} & \multicolumn{16}{|c|}{ Recovery (\%) } & \multirow[b]{2}{*}{$Y_{18}$} \\
\hline & $x_{1}(\mathrm{~min})$ & $x_{2}\left({ }^{\circ} \mathrm{C}\right)$ & $x_{3}(\mathrm{~mL})$ & & $Y_{1}$ & $Y_{2}$ & $Y_{3}$ & $\gamma_{4}$ & $Y_{5}$ & $Y_{6}$ & $y_{7}$ & $\gamma_{8}$ & $Y_{9}$ & $Y_{10}$ & $Y_{11,12}$ & $Y_{13}$ & $Y_{14}$ & $Y_{15}$ & $Y_{16}$ & $Y_{17}$ & \\
\hline 1 & $15(-)$ & $100(-)$ & $15(-)$ & $1(-)$ & 76.6 & 88.8 & 83.1 & 87.6 & 89.8 & 81.8 & 86.6 & 76.7 & 75.0 & 84.3 & 73.8 & 72.3 & 69.4 & 55.7 & 64.3 & 54.7 & 58.0 \\
\hline 2 & $15(-)$ & $100(-)$ & $15(-)$ & $3(+)$ & 81.8 & 68.9 & 83.3 & 89.7 & 85.8 & 87.2 & 84.4 & 76.6 & 78.0 & 84.7 & 75.7 & 74.8 & 71.8 & 58.5 & 68.0 & 59.6 & 61.0 \\
\hline 3 & $15(-)$ & $100(-)$ & $25(+)$ & $1(-)$ & 72.0 & 72.5 & 78.6 & 80.8 & 58.6 & 82.1 & 82.1 & 82.3 & 76.9 & 89.5 & 71.2 & 71.4 & 66.1 & 54.9 & 72.4 & 60.2 & 65.1 \\
\hline 4 & $15(-)$ & $100(-)$ & $25(+)$ & $3(+)$ & 77.1 & 0.0 & 77.1 & 79.9 & 69.5 & 79.3 & 79.9 & 80.0 & 70.4 & 77.8 & 68.4 & 67.7 & 63.3 & 48.9 & 63.6 & 52.7 & 55.8 \\
\hline 5 & $15(-)$ & $120(+)$ & $15(-)$ & $1(-)$ & 87.7 & 88.2 & 83.3 & 87.3 & 83.3 & 83.6 & 96.3 & 87.1 & 75.4 & 81.4 & 76.2 & 75.9 & 71.9 & 62.3 & 81.8 & 62.4 & 62.0 \\
\hline 6 & $15(-)$ & $120(+)$ & $15(-)$ & $3(+)$ & 72.3 & 68.7 & 78.1 & 82.6 & 69.4 & 82.8 & 82.2 & 72.6 & 74.2 & 80.6 & 73.5 & 71.3 & 67.6 & 59.4 & 81.3 & 59.1 & 59.5 \\
\hline 7 & $15(-)$ & $120(+)$ & $25(+)$ & $1(-)$ & 78.6 & 89.5 & 77.0 & 55.2 & 0.0 & 85.5 & 81.7 & 69.6 & 71.5 & 88.2 & 69.8 & 69.2 & 64.2 & 51.0 & 77.8 & 54.6 & 54.7 \\
\hline 8 & $15(-)$ & $120(+)$ & $25(+)$ & $3(+)$ & 0.0 & 63.5 & 77.8 & 64.7 & 0.0 & 83.0 & 84.1 & 71.2 & 71.7 & 76.1 & 69.7 & 70.8 & 66.4 & 55.9 & 72.5 & 59.0 & 60.8 \\
\hline 9 & $25(+)$ & $100(-)$ & $15(-)$ & $1(-)$ & 59.3 & 23.4 & 80.2 & 89.6 & 88.2 & 88.8 & 90.3 & 78.5 & 73.9 & 81.1 & 74.9 & 75.5 & 73.6 & 61.6 & 73.8 & 68.1 & 63.6 \\
\hline 10 & $25(+)$ & $100(-)$ & $15(-)$ & $3(+)$ & 68.4 & 76.7 & 88.6 & 89.1 & 71.8 & 90.0 & 88.2 & 90.8 & 74.5 & 74.6 & 75.5 & 77.7 & 72.4 & 63.3 & 86.2 & 66.5 & 66.1 \\
\hline 11 & $25(+)$ & $100(-)$ & $25(+)$ & $1(-)$ & 48.4 & 27.6 & 81.7 & 72.0 & 61.1 & 85.4 & 81.1 & 74.3 & 68.4 & 74.0 & 72.5 & 74.0 & 70.2 & 55.4 & 84.1 & 58.8 & 53.6 \\
\hline 12 & $25(+)$ & $100(-)$ & $25(+)$ & $3(-)$ & 47.7 & 50.2 & 81.8 & 78.3 & 72.5 & 80.1 & 84.6 & 71.4 & 69.1 & 72.4 & 72.0 & 72.6 & 68.0 & 55.5 & 78.5 & 61.5 & 57.4 \\
\hline 13 & $25(+)$ & $120(+)$ & $15(-)$ & $1(+)$ & 84.9 & 82.2 & 75.5 & 78.7 & 77.9 & 86.2 & 90.7 & 79.5 & 80.8 & 78.1 & 75.2 & 74.7 & 71.3 & 61.1 & 80.5 & 64.9 & 63.1 \\
\hline 14 & $25(+)$ & $120(+)$ & $15(-)$ & $3(-)$ & 88.3 & 100 & 75.8 & 81.3 & 74.0 & 83.1 & 89.4 & 70.9 & 73.9 & 68.9 & 72.7 & 72.7 & 69.1 & 58.4 & 97.2 & 64.5 & 55.2 \\
\hline 15 & $25(+)$ & $120(+)$ & $25(+)$ & $1(+)$ & 71.4 & 71.5 & 82.6 & 81.6 & 66.7 & 80.8 & 83.8 & 72.2 & 75.1 & 73.3 & 73.6 & 73.1 & 69.3 & 56.2 & 85.8 & 67.8 & 58.9 \\
\hline 16 & $25(+)$ & $120(+)$ & $25(+)$ & $3(-)$ & 38.9 & 0.0 & 72.9 & 74.5 & 62.0 & 78.7 & 91.9 & 75.0 & 75.7 & 72.7 & 71.8 & 69.2 & 64.9 & 53.4 & 77.7 & 60.8 & 61.6 \\
\hline $17(\mathrm{CP})$ & $20(0)$ & $110(0)$ & $20(0)$ & $2(0)$ & 79.5 & 79.9 & 85.5 & 87.7 & 74.1 & 93.5 & 90.0 & 89.5 & 74.6 & 83.8 & 72.6 & 73.5 & 67.5 & 52.8 & 68.8 & 59.1 & 59.0 \\
\hline $18(\mathrm{CP})$ & $20(0)$ & $110(0)$ & $20(0)$ & $2(0)$ & 84.9 & 78.4 & 83.4 & 88.5 & 81.9 & 89.9 & 93.8 & 82.4 & 77.4 & 86.3 & 72.3 & 73.4 & 69.0 & 57.3 & 70.9 & 62.7 & 62.5 \\
\hline 19 (CP) & $20(0)$ & $110(0)$ & $20(0)$ & $2(0)$ & 83.0 & 97.9 & 83.5 & 87.8 & 78.3 & 91.5 & 96.4 & 89.8 & 76.1 & 88.2 & 69.6 & 73.7 & 68.5 & 55.2 & 70.6 & 58.6 & 56.7 \\
\hline 20 (CP) & $20(0)$ & $110(0)$ & $20(0)$ & $2(0)$ & 79.1 & 52.5 & 78.9 & 84.5 & 84.1 & 84.9 & 91.2 & 88.4 & 75.8 & 82.0 & 70.9 & 70.5 & 67.1 & 54.4 & 77.9 & 58.4 & 65.3 \\
\hline $21(\mathrm{CP})$ & $20(0)$ & $110(0)$ & $20(0)$ & $2(0)$ & 80.7 & 98.1 & 86.5 & 87.8 & 71.5 & 87.4 & 87.5 & 90.6 & 78.2 & 78.3 & 73.4 & 74.2 & 69.8 & 55.3 & 71.4 & 65.1 & 70.8 \\
\hline 22 (CP) & $20(0)$ & $110(0)$ & $20(0)$ & $2(0)$ & 86.1 & 80.5 & 85.1 & 89.1 & 83.9 & 89.3 & 90.0 & 84.3 & 78.0 & 86.7 & 74.0 & 75.1 & 70.1 & 58.3 & 66.8 & 61.9 & 60.6 \\
\hline $23(\mathrm{CP})$ & $20(0)$ & $110(0)$ & $20(0)$ & $2(0)$ & 86.0 & 63.0 & 84.3 & 88.9 & 82.5 & 90.6 & 94.4 & 86.3 & 78.0 & 84.5 & 72.5 & 73.5 & 69.7 & 55.7 & 68.6 & 62.8 & 59.9 \\
\hline $24(\mathrm{CP})$ & $20(0)$ & $110(0)$ & $20(0)$ & $2(0)$ & 84.6 & 80.5 & 83.1 & 86.6 & 81.6 & 89.6 & 93.5 & 80.1 & 77.1 & 84.4 & 72.1 & 73.1 & 68.8 & 57.1 & 68.4 & 61.0 & 61.3 \\
\hline 25 (CP) & $20(0)$ & $110(0)$ & $20(0)$ & $2(0)$ & 85.5 & 60.3 & 80.2 & 85.2 & 83.7 & 88.3 & 94.2 & 89.4 & 76.0 & 88.0 & 72.4 & 72.1 & 67.1 & 55.3 & 75.3 & 59.2 & 58.6 \\
\hline $26(\mathrm{CP})$ & $20(0)$ & $110(0)$ & $20(0)$ & $2(0)$ & 81.8 & 95.8 & 78.6 & 82.6 & 75.1 & 89.5 & 94.3 & 90.5 & 74.4 & 86.7 & 69.8 & 72.1 & 67.1 & 54.0 & 69.1 & 57.4 & 55.9 \\
\hline $27(\mathrm{CP})$ & $20(0)$ & $110(0)$ & $20(0)$ & $2(0)$ & 80.0 & 97.3 & 85.8 & 87.0 & 70.9 & 86.6 & 86.7 & 89.8 & 77.6 & 77.6 & 72.8 & 73.6 & 69.1 & 54.8 & 70.8 & 64.5 & 70.2 \\
\hline $28(C P)$ & $20(0)$ & $110(0)$ & $20(0)$ & $2(0)$ & 83.9 & 78.4 & 82.9 & 86.8 & 81.7 & 87.0 & 87.8 & 82.1 & 76.0 & 84.5 & 72.0 & 73.1 & 68.3 & 56.8 & 65.1 & 60.3 & 59.0 \\
\hline \multicolumn{22}{|c|}{ Additional runs - model expansion } \\
\hline 29 & $10\left(-2^{4 / 4}\right)$ & $110(0)$ & $20(0)$ & $2(0)$ & 49.8 & 74.0 & 80.1 & 83.1 & 75.6 & 81.4 & 75.8 & 68.3 & 72.5 & 75.5 & 70.7 & 70.9 & 66.4 & 54.3 & 77.2 & 56.7 & 57.7 \\
\hline 30 & $30\left(+2^{4 / 4}\right)$ & $110(0)$ & $20(0)$ & $2(0)$ & 81.6 & 90.9 & 82.1 & 72.4 & 54.5 & 87.6 & 79.2 & 73.3 & 74.8 & 76.2 & 73.1 & 72.9 & 67.5 & 56.8 & 78.0 & 59.1 & 62.0 \\
\hline 31 & $20(0)$ & $90\left(-2^{4 / 4}\right)$ & $20(0)$ & $2(0)$ & 74.8 & 81.8 & 84.1 & 87.2 & 81.6 & 84.9 & 79.7 & 76.1 & 79.2 & 89.1 & 73.5 & 72.6 & 68.9 & 58.2 & 73.3 & 57.7 & 66.2 \\
\hline 32 & $20(0)$ & $130\left(+2^{4 / 4}\right)$ & $20(0)$ & $2(0)$ & 75.3 & 70.8 & 74.9 & 79.3 & 64.3 & 82.9 & 83.6 & 85.8 & 71.0 & 71.8 & 72.4 & 70.4 & 67.8 & 54.5 & 69.9 & 60.8 & 59.2 \\
\hline 33 & $20(0)$ & $110(0)$ & $10\left(-2^{4 / 4}\right)$ & $2(0)$ & 91.1 & 92.2 & 90.7 & 97.5 & 88.4 & 98.4 & 98.9 & 93.3 & 90.4 & 90.1 & 85.7 & 87.6 & 81.6 & 71.5 & 85.5 & 77.0 & 75.3 \\
\hline 34 & $20(0)$ & $110(0)$ & $30\left(+2^{4 / 4}\right)$ & $2(0)$ & 0.0 & 0.0 & 81.2 & 69.8 & 22.5 & 77.5 & 77.0 & 79.3 & 76.4 & 78.5 & 68.5 & 69.1 & 63.3 & 50.2 & 68.2 & 57.5 & 59.8 \\
\hline 35 & $20(0)$ & $110(0)$ & $20(0)$ & $0\left(-2^{4 / 4}\right)$ & 76.7 & 47.0 & 77.1 & 82.8 & 86.7 & 86.6 & 83.0 & 91.0 & 77.0 & 86.5 & 75.6 & 74.9 & 70.3 & 56.9 & 73.8 & 63.5 & 54.9 \\
\hline 36 & $20(0)$ & $110(0)$ & $20(0)$ & n.a. $\left(+2^{4 / 4}\right)$ & n.d. & n.d. & n.d. & n.d. & n.d. & n.d. & n.d. & n.d. & n.d. & n.d. & n.d. & n.d. & n.d. & n.d. & n.d. & n.d. & n.d. \\
\hline
\end{tabular}

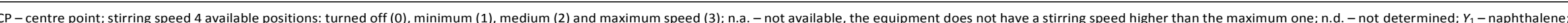

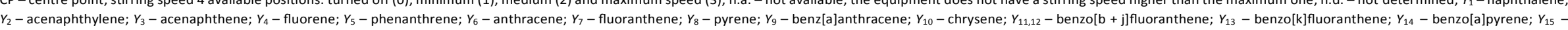
dibenzo[a,I]pyrene; $Y_{16}$ - dibenz[a,h]anthracene; $Y_{17}$ - benzo[g,h,i]perylene; $Y_{18}$ - indeno[1,2,3-cd]pyrene. 
Table 3

Analysis of variance (ANOVA) of the regression models for the compounds.

\begin{tabular}{|c|c|c|c|c|c|c|}
\hline \multirow[t]{2}{*}{ Response (\%) } & \multirow[b]{2}{*}{ Source } & \multicolumn{5}{|c|}{ Regression models } \\
\hline & & SS & DF & MS & $F$ value & $p$ \\
\hline \multirow[t]{6}{*}{$Y_{1}$} & Model & 13,777 & 14 & 984 & 8.36 & $<0.0001$ \\
\hline & Residual & 2355 & 20 & 117.7 & & \\
\hline & Lack of fit & 2280 & 9 & 253.3 & 37.0 & $<0.0001$ \\
\hline & Pureerror & 75.3 & 11 & 6.85 & 143.8 & $<0.0001$ \\
\hline & Total & 16,132 & 34 & & & \\
\hline & $R^{2}$ & 0.8540 & & & & \\
\hline \multirow[t]{6}{*}{$Y_{2}$} & Model & 17,457 & 14 & 1247 & 2.70 & 0.0212 \\
\hline & Residual & 9250 & 20 & 462.5 & & \\
\hline & Lack of fit & 6617 & 9 & 735.3 & 3.07 & 0.0416 \\
\hline & Pureerror & 2632 & 11 & 239 & 5.21 & 0.0046 \\
\hline & Total & 26,706 & 34 & & & \\
\hline & $R^{2}$ & 0.6537 & & & & \\
\hline \multirow[t]{6}{*}{$Y_{3}$} & Model & 397.2 & 14 & 28.4 & 3.93 & 0.0028 \\
\hline & Residual & 144.2 & 20 & 7.212 & & \\
\hline & Lack of fit & 68.17 & 9 & 7.575 & 1.10 & 0.4359 \\
\hline & Pureerror & 76.07 & 11 & 6.92 & 4.10 & 0.0119 \\
\hline & Total & 541.5 & 34 & & & \\
\hline & $R^{2}$ & 0.7336 & & & & \\
\hline \multirow[t]{6}{*}{$Y_{4}$} & Model & 1796 & 14 & 128 & 5.48 & 0.0003 \\
\hline & Residual & 468.6 & 20 & 23.43 & & \\
\hline & Lack of fit & 428.2 & 9 & 47.57 & 13.0 & 0.00012 \\
\hline & Pureerror & 40.40 & 11 & 3.67 & 34.93 & $<0.0001$ \\
\hline & Total & 2264 & 34 & & & \\
\hline & $R^{2}$ & 0.7931 & & & & \\
\hline \multirow[t]{6}{*}{$\gamma_{5}$} & Model & 13,777 & 14 & 984 & 8.96 & $<0.0001$ \\
\hline & Residual & 2197 & 20 & 109.8 & & \\
\hline & Lack of fit & 2001 & 9 & 222.3 & 12.5 & 0.00014 \\
\hline & Pureerror & 195.7 & 11 & 17.79 & 55.31 & $<0.0001$ \\
\hline & Total & 15,974 & 34 & & & \\
\hline & $R^{2}$ & 0.8625 & & & & \\
\hline \multirow[t]{6}{*}{$Y_{6}$} & Model & 524.4 & 14 & 37.5 & 4.59 & 0.0011 \\
\hline & Residual & 163.3 & 20 & 8.165 & & \\
\hline & Lack of fit & 102.9 & 9 & 11.43 & 2.08 & 0.1254 \\
\hline & Pureerror & 60.39 & 11 & 5.49 & 6.82 & 0.0014 \\
\hline & Total & 687.7 & 34 & & & \\
\hline & $R^{2}$ & 0.7626 & & & & \\
\hline \multirow[t]{6}{*}{$Y_{7}$} & Model & 928.7 & 14 & 66.3 & 4.64 & 0.0010 \\
\hline & Residual & 285.8 & 20 & 14.29 & & \\
\hline & Lack of fit & 170.3 & 9 & 18.93 & 1.80 & 0.1766 \\
\hline & Pureerror & 115.5 & 11 & 10.50 & 6.32 & 0.0020 \\
\hline & Total & 1214 & 34 & & & \\
\hline & $R^{2}$ & 0.7647 & & & & \\
\hline \multirow[t]{6}{*}{$Y_{8}$} & Model & 1241 & 14 & 88.6 & 2.57 & 0.0264 \\
\hline & Residual & 689.1 & 20 & 34.45 & & \\
\hline & Lack of fit & 533.5 & 9 & 59.28 & 4.19 & 0.0145 \\
\hline & Pureerror & 155.6 & 11 & 14.14 & 6.27 & 0.0021 \\
\hline & Total & 1930 & 34 & & & \\
\hline & $R^{2}$ & 0.6430 & & & & \\
\hline$Y_{9}$ & Model & 328.4 & 14 & 23.5 & 2.83 & 0.0166 \\
\hline & Residual & 165.6 & 20 & 8.278 & & \\
\hline & Lack of fit & 146.9 & 9 & 16.32 & 9.62 & 0.0005 \\
\hline & Pureerror & 18.66 & 11 & 1.70 & 13.82 & $<0.0001$ \\
\hline & Total & 493.9 & 34 & & & \\
\hline & $R^{2}$ & 0.6648 & & & & \\
\hline$Y_{10}$ & Model & 792.2 & 14 & 56.6 & 2.71 & 0.0206 \\
\hline & Residual & 417.5 & 20 & 20.87 & & \\
\hline & Lack of fit & 286.3 & 9 & 31.81 & 2.67 & 0.0641 \\
\hline & Pureerror & 131.2 & 11 & 11.93 & 4.74 & 0.0067 \\
\hline & Total & 1210 & 34 & & & \\
\hline & $R^{2}$ & 0.6549 & & & & \\
\hline$Y_{11,12}$ & Model & 238.1 & 14 & 17.0 & 5.09 & 0.0005 \\
\hline & Residual & 66.86 & 20 & 3.343 & & \\
\hline & Lack of fit & 48.14 & 9 & 5.349 & 3.14 & 0.0387 \\
\hline & Pureerror & 18.72 & 11 & 1.70 & 10.00 & 0.0003 \\
\hline & Total & 305.0 & 34 & & & \\
\hline & $R^{2}$ & 0.7808 & & & & \\
\hline$Y_{13}$ & Model & 278.3 & 14 & 19.9 & 4.36 & 0.0015 \\
\hline & Residual & 91.23 & 20 & 4.562 & & \\
\hline
\end{tabular}

Table 3 (continued)

\begin{tabular}{|c|c|c|c|c|c|c|}
\hline \multirow[t]{2}{*}{ Response (\%) } & \multirow[b]{2}{*}{ Source } & \multicolumn{5}{|c|}{ Regression models } \\
\hline & & SS & DF & MS & $F$ value & $p$ \\
\hline & Lack of fit & 76.69 & 9 & 8.521 & 6.44 & 0.0027 \\
\hline & Pureerror & 14.55 & 11 & 1.32 & 15.03 & $<0.0001$ \\
\hline & Total & 369.5 & 34 & & & \\
\hline & $R^{2}$ & 0.7531 & & & & \\
\hline \multirow[t]{6}{*}{$Y_{14}$} & Model & 298.1 & 14 & 21.3 & 6.29 & 0.00013 \\
\hline & Residual & 67.74 & 20 & 3.387 & & \\
\hline & Lack of fit & 54.25 & 9 & 6.028 & 4.91 & 0.0080 \\
\hline & Pureerror & 13.50 & 11 & 1.23 & 17.35 & $<0.0001$ \\
\hline & Total & 365.8 & 34 & & & \\
\hline & $R^{2}$ & 0.8148 & & & & \\
\hline \multirow[t]{6}{*}{$Y_{15}$} & Model & 448.4 & 14 & 32.0 & 5.71 & 0.00025 \\
\hline & Residual & 112.2 & 20 & 5.608 & & \\
\hline & Lack of fit & 84.83 & 9 & 9.425 & 3.79 & 0.0206 \\
\hline & Pureerror & 27.33 & 11 & 2.48 & 12.89 & $<0.0001$ \\
\hline & Total & 560.6 & 34 & & & \\
\hline & $R^{2}$ & 0.7999 & & & & \\
\hline \multirow[t]{6}{*}{$Y_{16}$} & Model & 1344 & 14 & 96.0 & 3.66 & 0.0042 \\
\hline & Residual & 523.9 & 20 & 26.19 & & \\
\hline & Lack of fit & 389.2 & 9 & 43.24 & 3.53 & 0.0264 \\
\hline & Pureerror & 134.7 & 11 & 12.24 & 7.84 & 0.0008 \\
\hline & Total & 1868 & 34 & & & \\
\hline & $R^{2}$ & 0.7195 & & & & \\
\hline \multirow[t]{6}{*}{$Y_{17}$} & Model & 429.8 & 14 & 30.7 & 2.30 & 0.0431 \\
\hline & Residual & 266.5 & 20 & 13.32 & & \\
\hline & Lack of fit & 198.1 & 9 & 22.01 & 3.54 & 0.0261 \\
\hline & Pureerror & 68.37 & 11 & 6.22 & 4.94 & 0.0057 \\
\hline & Total & 696.3 & 34 & & & \\
\hline & $R^{2}$ & 0.6173 & & & & \\
\hline \multirow[t]{6}{*}{$Y_{18}$} & Model & 308.0 & 14 & 22.0 & 0.92 & 0.5539 \\
\hline & Residual & 477.9 & 20 & 23.89 & & \\
\hline & Lack of fit & 221.9 & 9 & 24.66 & 1.06 & 0.4560 \\
\hline & Pureerror & 256.0 & 11 & 23.27 & 0.95 & 0.5477 \\
\hline & Total & 785.8 & 34 & & & \\
\hline & $R^{2}$ & 0.3919 & & & & \\
\hline
\end{tabular}

$Y_{1}$ - naphthalene; $Y_{2}$ - acenaphthylene; $Y_{3}$ - acenaphthene; $Y_{4}$ - fluorene; $Y_{5}-$ phenanthrene; $Y_{6}$ - anthracene; $Y_{7}$ - fluoranthene; $Y_{8}$ - pyrene; $Y_{9}$ - benz[a]anthracene; $Y_{10}$ - chrysene; $Y_{11,12}$ - benzo[b + j]fluoranthene; $Y_{13}$ - benzo[k]fluoranthene; $Y_{14}-$ benzo[a]pyrene; $Y_{15}$ - dibenzo[a,l]pyrene; $Y_{16}$ - dibenz[a,h]anthracene; $Y_{17}$ benzo[g,h,i]perylene; $Y_{18}$-indeno[1,2,3-cd]pyrene;

$\mathrm{SS}=$ Sum of squares; $\mathrm{DF}=$ Degree of freedom; MS = Mean square; $R^{2}=$ Quadratic correlation coefficient.

nature (>0.8 (Montgomery, 1991)), advocating a good correlation between observed and predicted values. For $Y_{3}$ and $Y_{16}$, this statis- tical parameter fell in the range $0.7<R^{2}<0.8$ where as for $Y_{2}, Y_{8-10}$ and $Y_{17}, 0.6<$ $R^{2}<0.7$. Indeno[1,2,3,cd]pyrene regression equation

$\left(Y_{18}\right)$ presented the lowest $R^{2}$ stating a poor model predictability. Also, experimental pure errors of the models were in line with this and all reached statistical significance $\left(p<0.05 ; Y_{1}-Y_{17}\right.$ in Table 3$)$ with the exception of $Y_{18}(p>0.05$ in Table 3$)$.

Globally, maximum recoveries were obtained for solvent vol- ume fixed at lowest level $(10 \mathrm{ml})$ and remain factors at zero levels(run 33 in Table 2; 20 min of extraction, $110^{\circ} \mathrm{C}, 10 \mathrm{~mL}$ of solvent and medium agitation). This result was in accordance with ANOVA information, with solvent volume linear effect $\left(X_{3} ; p<0.05\right.$ Table 3$)$ being without question, the most influential parameter in $\mathrm{PAH}$ recoveries, producing a negative effect in almost all responses ( $Y_{1}-Y_{18}$ with the exception of $Y_{10}$ (chrysene) in Table 2). 3D surfaceplots corroborated these findings (see Supplementary material Fig. S1). Another main factor that influenced the responses studied was the extraction temperature $\left(X_{2} ; p<0.05\right)$ with $Y_{3-5}$ and $Y_{10}$ decreasing when increments in this parameter were performed (e.g. for $Y_{10}$ Supplementary material Fig. S1d). Oppositely, a posi- tive correlation was observed between $Y_{16}$ and $X_{2}(p<0.05)$. Again, experimental results (runs 31 and 32 , temperature at lowest $\left(90^{\circ} \mathrm{C}\right)$ and highest $\left(130^{\circ} \mathrm{C}\right)$ levels, respectively with fixing all re-main factors at zero level; Table 2 ) were related with these facts. 
Table 4

Average retention time and calibration data obtained using matrix matched standards for the selected PAHs.

\begin{tabular}{|c|c|c|c|c|c|c|c|c|}
\hline \multirow[b]{2}{*}{ Compound } & \multirow[b]{2}{*}{$\begin{array}{l}\text { Retention time } \\
(\mathrm{min})\end{array}$} & \multirow[b]{2}{*}{$\begin{array}{l}\text { Calibration range } \\
(\mathrm{Ig} / \mathrm{L} ; n=6)\end{array}$} & \multirow[b]{2}{*}{$\begin{array}{l}\text { Regression } \\
\text { equation }^{a}(n=6)\end{array}$} & \multirow[b]{2}{*}{$R^{2}$} & \\
\hline & & & & & $\begin{array}{l}\text { LOD } \\
(\mathrm{Ig} / \mathrm{L})\end{array}$ & $\begin{array}{l}\text { LOD (ng/g } \\
\text { wet weight) }\end{array}$ & $\begin{array}{l}\mathrm{LOQ} \\
(\mathrm{Ig} / \mathrm{L})\end{array}$ & $\begin{array}{l}\text { LOQ ( } \mathrm{ng} / \mathrm{g} \\
\text { wet weight) }\end{array}$ \\
\hline Naphthalene, $Y_{1}$ & 10.1 & $4.7-200.6$ & $y=15,010 x-5659$ & 0.99996 & 1.42 & 0.71 & 4.73 & 2.37 \\
\hline Acenaphthylene, $Y_{2}$ & 11.5 & $54.3-700.3$ & $y=268 x+3455$ & 0.99949 & 16.30 & 8.15 & 54.33 & 27.16 \\
\hline Acenaphthene, $Y_{3}$ & 13.3 & $3.7-200.6$ & $y=19,364 x-5533$ & 0.99998 & 1.10 & 0.55 & 3.67 & 1.83 \\
\hline Fluorene, $Y_{4}$ & 13.8 & $0.6-39.6$ & $y=23,9390 x-3720$ & 0.99998 & 0.18 & 0.09 & 0.62 & 0.31 \\
\hline Phenanthrene, $Y_{5}$ & 14.9 & $0.3-20.0$ & $y=63,937 x-3311$ & 0.99998 & 0.10 & 0.05 & 0.32 & 0.16 \\
\hline Anthracene, $Y_{6}$ & 15.8 & $0.5-20.0$ & $y=40,908 x+1580$ & 0.99995 & 0.15 & 0.08 & 0.51 & 0.25 \\
\hline Fluoranthene, $Y_{7}$ & 17.0 & $0.8-39.5$ & $y=17,966 x-5809$ & 0.99997 & 0.24 & 0.12 & 0.79 & 0.40 \\
\hline Pyrene, $Y_{8}$ & 17.8 & $0.7-19.4$ & $y=16,818 x+2604$ & 0.99992 & 0.20 & 0.10 & 0.66 & 0.33 \\
\hline Benz[a]anthracene, $Y_{9}$ & 20.2 & $0.5-19.7$ & $y=54,000 x+4050$ & 0.99996 & 0.14 & 0.07 & 0.46 & 0.23 \\
\hline Chrysene, $Y_{10}$ & 21.2 & $0.3-19.8$ & $y=19,583 x-3807$ & 0.99998 & 0.10 & 0.05 & 0.33 & 0.16 \\
\hline Benzo[b $+\mathrm{j}]$ fluoranthene, $Y_{11,12}$ & 22.8 & $1.9-80.2$ & $y=48,290 x-2370$ & 0.99996 & 0.57 & 0.29 & 1.91 & 0.96 \\
\hline Benzo[k]fluoranthene, $Y_{13}$ & 24.0 & $0.3-20.0$ & $y=20,2967 x-8515$ & 0.99998 & 0.09 & 0.04 & 0.30 & 0.15 \\
\hline Benzo[a]pyrene, $Y_{14}$ & 25.0 & $0.6-20.1$ & $y=24,1455 x-7797$ & 0.99993 & 0.19 & 0.09 & 0.63 & 0.31 \\
\hline Dibenzo[a,l]pyrene, $Y_{15}$ & 25.6 & $1.5-40.0$ & $y=50,294 x-14,321$ & 0.99999 & 0.46 & 0.23 & 1.52 & 0.76 \\
\hline Dibenz[a,h]anthracene, $Y_{16}$ & 27.3 & $1.1-40.0$ & $y=11,215 x-7680$ & 0.99994 & 0.34 & 0.17 & 1.13 & 0.56 \\
\hline Benzo[g,h,i]perylene, $Y_{17}$ & 28.6 & $0.8-39.8$ & $y=55,263 x-4626$ & 0.99997 & 0.24 & 0.12 & 0.80 & 0.40 \\
\hline Indeno[1,2,3-cd]pyrene, $Y_{18}$ & 30.9 & $0.4-20.1$ & $y=12,720 x-9022$ & 0.99997 & 0.13 & 0.06 & 0.42 & 0.21 \\
\hline
\end{tabular}

${ }^{a} y$ - area; $x$ - concentration $(\mathbf{I g} / \mathrm{L})$.

Regarding quadratic effects, solvent volume $\left(X^{2} ; p<0.0 .5\right)$ and extraction time $\left(X^{2} ; p<0.05\right)$ were the most influent parameters (data not shown). For instance, $X^{2}$ positively influenced seyeral PAH recoveries $\left(Y_{9}\right.$ and $Y_{11-17}$; e.g. Supplementary material Fig. S1b and c) whereas, opposite influence was observed for naph- thalene response $\left(Y_{1}\right.$; Supplementary material Fig. S1a). $Y_{4-8}$ and

$Y_{10}$ were negatively related with $X^{2}$ ( $p<0,05$; e.g. Supplementary

material Fig. S1d) contrary to $Y_{16}$ that was directly correlated with this effect. Experimental results (runs 29-30 and 33-34 in Table 2) and 3D surface plots corroborated these findings.

In general, interaction between factors had little few statistical relevance in the responses evaluated. Nevertheless, naphthalene recovery $\left(Y_{1}\right)$ was affected by several interaction parameters such as, $X_{1} X_{2}, X_{2} X_{3}, X_{2} X_{4}$ and $X_{3} X_{4}$ $(p<0.05)$. For instance, extraction temperature and stirring speed interaction $\left(X_{2} X_{4}\right)$ produced a remarkable negative effect in $Y_{1}$ and these facts were again in accordance with 3D surface plots (not shown) and experimental observations (Table 2).

Therefore, in order to select the optimum MAE conditions, six possible optimum runs were tested: Test I: $30 \mathrm{~min}$ of extraction, $130^{\circ} \mathrm{C}, 10$ $\mathrm{mL}$ of solvent and no agitation; Test II: 10 min of extrac- tion, $90^{\circ} \mathrm{C}, 10 \mathrm{~mL}$ of solvent and medium agitation; Test III: $10 \mathrm{~min}$ of extraction, $90^{\circ} \mathrm{C}, 10 \mathrm{~mL}$ of solvent and no agitation; Test IV: $20 \mathrm{~min}$ of extraction, $110^{\circ} \mathrm{C}, 10 \mathrm{~mL}$ of solvent and medium agita- tion; Test V: $20 \mathrm{~min}$ of extraction, $120^{\circ} \mathrm{C}, 10$ $\mathrm{mL}$ of solvent and no agitation; Test VI: $15 \mathrm{~min}$ of extraction, $90{ }^{\circ} \mathrm{C}, 10 \mathrm{~mL}$ of solvent and no agitation. Fourteen responses were maximised simultaneously with run IV operational parameters (optimum run corre- sponding to run 33 conditions; results for spiking level II in Table

1) including benzo[a]pyrene and dibenzo[a,I]pyrene recoveries, the most carcinogenic target compounds studied (exception oc- curred with fluorene $\left(Y_{4} ; 84.4 \pm 3.0 \%\right)$, phenanthrene $\left(Y_{5} ; 66.8 \pm 2.8 \%\right)$, chrysene $\left(Y_{10}\right.$; $86.2 \pm 3.7 \%)$ and dibenz $[a, h]$ anthracene $\left(Y_{16}\right.$;

$79.3 \pm 2.8 \%)$. Nevertheless, for this group of PAHs the recoveries at-

tained were clearly acceptable. Therefore, $20 \mathrm{~min}$ of extraction, $110^{\circ} \mathrm{C}$, $10 \mathrm{~mL}$ of solvent and medium stirring speed was the opti- mal conditions selected.

\subsection{Validation of microwave-assisted extraction}

As the PAHs concentration level can affect the efficiency of the extraction, the optimal conditions of MAE reached by RSM for the spiking level II were applied to sardine samples fortified with other levels. Three spiking levels (Table 1 ) were chosen in order to test the recovery values over a certain concentration range. The spiking level IV was chosen in order to include the maximum admissible concentration for benzo[a]pyrene in fish muscle fixed at $2 \mathrm{ng} / \mathrm{g}$ wet weight by the European Regulation 1881/2006/EC (Commis- sion Regulation, 2006). The results obtained are displayed in Table

1. The extraction efficiency was consistent over the entire range of concentrations. Quantitative extraction (>70\%) succeeded for all PAHs except for phenanthrene $(65.0 \pm 3.0 \%$ for level IV) and diben- zo[a,I]pyrene ( $64.5 \pm 3.5$ and $67.0 \pm 2.2 \%$ for levels III and IV, respectively). Acenaphthene and fluorene were the most affectedcompounds by the decrease of the fortification level from I to IV $(96.4 \pm 1.6-79.8 \pm 8.5 \%$ for acenaphthene and $89.3 \pm 1.5-$

$72.2 \pm 4.8 \%$ for fluorene). Regarding the repeatability of the opti- mised methodology, expressed as RSD, values were lower than $9 \%$. The overall mean recoveries obtained at each level were

$85.1 \pm 8.9 \%$ for level I, $84.7 \pm 9.5 \%$ for level II, $82.3 \pm 9.3 \%$ for level III and $81.1 \pm 9.8 \%$ for level IV. The reported results are in accor- dance with previous related studies (Akpambang et al., 2009; El- Saeid, 2006; Pena et al., 2006; Soclo et al., 2008). Pena et al. (2006) quantified six PAHs (benz[a]anthracene, benzo[b]fluoranth- ene, benzo[k]fluoranthene, benzo[a]pyrene, dibenz[a,h]anthra- cene, indene[1,2,3-cd]pyrene) in turbot and salmon using simultaneous MAE of PAHs with $n$-hexane and lipids hydrolysis with potassium hydroxide (recoveries ranged between $85 \%$ and 100\%). El-Saeid (2006) extracted successfully (92\%) benzo[a]pyrene from spiked fresh, canned, smoked and salted cured fish samples. Soclo et al. (2008) reported recoveries ranging between $65 \%$ and $115 \%$ for twelve PAHs microwave extracted from fish, mollusks and shrimps originated from Benin coastal waters. Also, Akpam- bang et al. (2009) obtained recoveries ranging from $75 \%$ to $101 \%$ (16 USEPA PAHs) for Nigerian raw and smoked fish and meat.

Validation was also performed by using a certified reference material since spiked solid matrices are known to be more easily extractable than real environmental matrices. Although no SRM of naturally contaminated fish with PAHs was available, the developedmethodology was tested with a more difficult matrix, a SRM of freeze-dried tissue homogenate prepared from marine bivalve mollusk. Six portions of the NIST-SRM 2977 mussel tissue were pro- cessed using the optimal MAE conditions. This material has certified and reference concentrations for all the analysed PAHs except for acenaphthylene and dibenzo[a,l]pyrene. Measured and recovery values are summarised in Table 1. Naphthalene and chrysene were affected by the presence of co-extracted compounds and were impossible to quantify due to the occurrence of peak overlapping. 
Table 5

Average concentrations of detected PAHs in horse mackerel, chub mackerel and sardine samples ( $n$ P 3) purchased in the city of Oporto (NW Portugal).

\begin{tabular}{|c|c|c|c|c|c|}
\hline \multirow[t]{2}{*}{ Sample } & & \multicolumn{4}{|c|}{ Mean concentration $\pm \mathrm{SD}$ (ng/g wet weight) } \\
\hline & & Naphthalene & Fluorene & Phenanthrene & $\mathrm{PAHs} \pm \mathrm{SD}$ \\
\hline \multirow[t]{6}{*}{ Horse mackerel } & HM1 & $2.29 \pm 0.04$ & $0.40 \pm 0.01$ & $1.02 \pm 0.04$ & $3.71 \pm 0.96$ \\
\hline & HM2 & $2.27 \pm 0.04$ & $0.22 \pm 0.01$ & $0.74 \pm 0.03$ & $3.23 \pm 1.07$ \\
\hline & HM3 & $2.01 \pm 0.27$ & $0.35 \pm 0.01$ & $1.12 \pm 0.01$ & $3.48 \pm 1.04$ \\
\hline & HM4 & $2.51 \pm 0.05$ & $0.49 \pm 0.02$ & $1.20 \pm 0.04$ & $4.20 \pm 1.02$ \\
\hline & HM5 & $2.53 \pm 0.07$ & $0.55 \pm 0.01$ & $0.34 \pm 0.28$ & $3.42 \pm 1.21$ \\
\hline & HM6 & $1.78 \pm 0.04$ & $0.34 \pm 0.01$ & $1.07 \pm 0.01$ & $3.19 \pm 0.72$ \\
\hline \multirow[t]{6}{*}{ Chub mackerel } & $\mathrm{CH} 1$ & $2.76 \pm 0.14$ & $0.71 \pm 0.07$ & $1.45 \pm 0.02$ & $4.92 \pm 1.04$ \\
\hline & $\mathrm{CH} 2$ & $2.76 \pm 0.01$ & $0.55 \pm 0.01$ & $1.16 \pm 0.09$ & $4.47 \pm 1.14$ \\
\hline & CH3 & $2.95 \pm 0.04$ & $0.56 \pm 0.01$ & $1.27 \pm 0.03$ & $4.78 \pm 1.20$ \\
\hline & $\mathrm{CH} 4$ & $2.52 \pm 0.14$ & $0.48 \pm 0.05$ & $0.62 \pm 0.05$ & $3.62 \pm 1.14$ \\
\hline & $\mathrm{CH} 5$ & $1.03 \pm 0.10$ & $0.63 \pm 0.03$ & $0.63 \pm 0.01$ & $2.29 \pm 0.23$ \\
\hline & $\mathrm{CH} 6$ & $2.59 \pm 0.09$ & $0.63 \pm 0.03$ & $0.93 \pm 0.01$ & $4.15 \pm 1.06$ \\
\hline \multirow[t]{6}{*}{ Sardine } & SA1 & $1.03 \pm 0.15$ & $0.48 \pm 0.01$ & $2.40 \pm 0.02$ & $3.91 \pm 0.99$ \\
\hline & SA2 & $2.58 \pm 0.34$ & $0.44 \pm 0.01$ & $1.73 \pm 0.12$ & $4.75 \pm 1.08$ \\
\hline & SA3 & $2.07 \pm 0.45$ & $0.35 \pm 0.04$ & $1.59 \pm 0.06$ & $4.01 \pm 0.89$ \\
\hline & SA4 & $2.47 \pm 0.43$ & $0.44 \pm 0.06$ & $1.46 \pm 0.07$ & $4.37 \pm 1.02$ \\
\hline & SA5 & $2.38 \pm 0.09$ & $0.82 \pm 0.05$ & $2.76 \pm 0.51$ & $5.96 \pm 1.03$ \\
\hline & SA6 & $2.35 \pm 0.13$ & $1.09 \pm 0.15$ & $3.54 \pm 0.68$ & $6.98 \pm 1.23$ \\
\hline
\end{tabular}

Ramalhosa et al. (2009) reported the same problem in a previous study concerning extraction of 16 PAHs applying the QuEChERS ap- proach. The recoveries of all the other $\mathrm{PAHs}$ were in the range of

$58.5 \pm 5.0 \%$ (for fluorene) to $99.7 \pm 0.6 \%$ (for benzo[k]fluoranthene). Regarding the repeatability of the optimised methodology, ex- pressed as RSD, values were lower than $7 \%$. The results obtained are in general agreement with other works that used the same SRM 2977 and applied different $\mathrm{PAH}$ extraction procedures devel- oped specially for bivalve mollusks (Fernández-González et al., 2010; Fuoco et al., 2005; Pena et al., 2006; Sanz-Landaluze etal., 2006; Veyrandetal., 2007; Yusà, Pardo, Martí, \& Pastor, 2005). Fur- thermore, results are comparable or in line with those reached by Serpe et al. (2010) that validated a complex sample preparation methodology involving alkaline digestion, liquid-liquid extraction and solid phase clean-up for determination of $11 \mathrm{PAHs}$ in mussels by LC with fluorescence detection.

\subsection{Application to fish fillets}

PAH concentrations were measured in muscle fish tissues of horse mackerel, chub mackerel and sardine captured in Atlantic Ocean and commercially available to consumers in the Porto Metropolitan area (NW Portugal). The results reported for PAH lev- els are summarised in Table 5 (representative chromatograms of a sardine extract are presented in Supplementary material Fig. S2). Results were not corrected for recovery. Three (naphthalene, fluo- rene and phenanthrene) of the 18 tested PAHs were detected in the analysed samples. None of the analysed samples contained detect-able amounts of benzo[a]pyrene, the marker used for evaluating the occurrence and genotoxic and carcinogenic effects of PAHs in food. However, naphthalene which is classified by IARC as possible carcinogenic to humans (Group 2B; (IARC, 2010)) was the predominant compound. Fluorene and phenanthrene are included in Group 3Unclassifiable as carcinogenic in humans. Total PAH concentrations ranged between $3.19 \pm 0.72$ and $4.20 \pm 1.02 \mathrm{ng} / \mathrm{g}$

wet weight for horse mackerel, $2.29 \pm 0.23$ and $4.92 \pm 1.04 \mathrm{ng} / \mathrm{g}$

wet weight for chub mackerel, $3.91 \pm 0.99$ and $6.98 \pm 1.23 \mathrm{ng} / \mathrm{g}$ wet weight for sardine. Overall, these results are in agreement with those obtained in previous studies concerning horse mackerel (Ramalhosa et al., 2009), chub mackerel (Llobet et al., 2006; Perelló et al., 2009; Ramalhosa et al., 2009), and sardine (Ramalhosa et al., 2009). PAHs in fish muscles are bioaccumulated from water, suspended particulate matter and sediments via gills, skin, and ingestion of contaminated food or sediment. PAHs are lipophilic compounds. The highest mean amounts were found in the muscletissue of sardine which is the richest species in total fat (and the lowest in moisture contents) accordingly with the characterisation performed (results not shown). This observation indicates that bal-ancing adequately the risks and benefits of fish consumption, and

particularly of fatty fish, is currently a nutritional/environmental health key issue. Estimated daily intakes $(\mathrm{Ig} / \mathrm{kg}$ body weight per

day) were calculated using a body weight of $70 \mathrm{~kg}$, the per capita finfish world (12.2 kg/year per capita, (FAO, 2009)) and Portuguese consumption (55.6 kg/year per capita). The values obtained for in- take of naphthalene, the only detected $\mathrm{PAH}$ classified as possible carcinogenic to humans, reach a maximum of 0.0014 and

$0.0064 \mathrm{Ig} / \mathrm{kg}$ body weight (b.w.) per day (through chub mackerel consumption) for world and Portuguese per capita consumption, respectively.

\section{Conclusions}

The optimised method is a confirmed quantitative method that can be considered useful for routine analyses to monitor the 18 se-lected PAHs in fish samples. PAHs have a negative impact on health due to their potential cytotoxicity, mutagenicity and carcinogenic-ity in humans. Application of the validated procedure to three important pelagic fish species showed that these compounds should be subject to mandatory monitoring, particularly in fatty fish due to their lipophilic character. Furthermore, as PAHs are typ- ically found in a mixture of many compounds, the coexistence ofPAHs in various mixtures raises further questions that need to be correctly addressed.

\section{Acknowledgements}

Maria João Ramalhosa thanks Instituto Politécnico do Porto and Instituto Superior de Engenharia do Porto for her fellowship. The authors thank the Fundação para a Ciência e a Tecnologia (FCT) for the financial support through the project PTDC/AGR-AAM/ 102316/2008 (financed by COMPETE and FEDER). A doctoral fel- lowship from FCT to A.M.M. Sousa (SFRH/BD/64315/2009) is greatly acknowledged. 


\section{Appendix A. Supplementary data}

Supplementary data associated with this article can be found, in the online version, at http://dx.doi.org/10.1016/j.foodchem. 2012.04.078.

\section{References}

Akpambang, V. O. E., Purcaro, G., Lajide, L., Amoo, I. A., Conte, L. S., \& Moret, S. (2009). Determination of polycyclic aromatic hydrocarbons (PAHs) in commonly consumed Nigerian smoked/grilled fish and meat. Food Additives \& Contaminants: Part A, 26, 10961103.

AOAC. (2007). Official Methods of Analysis of AOAC International (18th ed.). Arlington: AOAC International.

Commission Regulation, (EU) No. 1881/2006 of December 2006. (2006). Setting maximum levels for certain contaminants in foodstuffs. This Regulation repels the Commission Regulation (EU) No. 208/2005 of February 2005

Duedahl-Olesen, L., \& Ghorbani, F. (2008). Optimization of large volume injection for improved detection of polycyclic aromatic hydrocarbons (PAH) in mussels. Polycyclic Aromatic Compounds, 28, 282-301

El-Saeid, M. H. (2006). Microwave solvent extraction (MSE) and high performance liquid chromatography (HPLC) as a rapid determination methods of benzo(a)pyrenein fish. Research Bulletin. No. 143. Food Science \& Agriculture Resource Center, King Saud University, 1-17.

European Commission. (2007). Regulation (EC) No. 333/2007 of 28 March 2007. Laying down the methods of sampling and analysis for the official control of the levels of lead, cadmium, mercury, inorganic tin, 3-MCPD and benzo(a)pyrene in foodstuffs. Brussels.

European Commission. (2010). Facts and figures on the CFP Basic data on the Common Fisheries Policy - Edition 2010. Office for Official Publications of the European Communities, Luxembourg. ISBN 978-92-79-14140-9, http:// dx.doi.org/10.2771/15477.

FAO. (2009). The State of World Fisheries and Aquaculture-2008. FAO Fisheries and Aquaculture Department. Food and Agriculture Organization of the United Nations. Rome.

Fernández-González, V., Concha-Graña, E., Muniategui-Lorenzo, S., López-Mahía, P., FernándezFernández, E., \& Prada-Rodríguez, D. (2010). A matrix solid-phase dispersion-gel permeation chromatography-programmed temperature vaporisation-GC-MS procedure for the analysis of polycyclic aromatic hydrocarbons in mussel samples. Journal of Separation Science, 33, 3741-3750. Fuoco, R., Giannarelli, S., Onor, M.,

Ceccarini, A., \& Carli, V. (2005). Optimized cleanup methods of organic extracts for the determination of organic pollutants in biological samples. Microchemical Journal, 79, 69-76.

IARC. (2010). Some non-heterocyclic polycyclic aromatic hydrocarbons and some related exposures. IARC Monographs on the Evaluation of Carcinogenic Risks to Humans, 92, 773.

Janska, M., Tomaniova, M., Hajslova, J., \& Kocourek, V. (2006). Optimization of the procedure for the determination of polycyclic aromatic hydrocarbons and their derivatives in fish tissue: Estimation of measurements uncertainty. Food Additives \& Contaminants: Part A, 23, 309-325.

Llobet, J. M., Falcó, G., Bocio, A., \& Domingo, J. L. (2006). Exposure to polycyclic aromatic hydrocarbons through consumption of edible marine species in Catalonia, Spain. Journal of Food Protection, 69, 2493-2499.

Maioli, O. L. G., Rodrigues, K. C., Knoppers, B. A., \& Azevedo, D. A. (2010). Polycyclic aromatic and aliphatic hydrocarbons in Mytella charruana, a bivalve mollusk from Mundaú Lagoon, Brazil. Microchemical Journal, 96, 172-179.

Miller, J. N., \& Miller, J. C. (2000). Statistics for analytical chemistry (4th ed.). Harlow:Pearson Education Limit.

Montgomery, D. C. (1991). Design and analysis of experiments (third ed.). New York: Wiley.
Pena, T., Pensado, L., Casais, C., Mejuto, C., Phan-Tan-Luu, R., \& Cela, R. (2006). Optimization of a microwave-assisted extraction method for the analysis of polycyclic aromatic hydrocarbons from fish samples. Journal of Chromatography A, 1121, 163-169.

Pensado, L., Casais, C., Mejuto, C., \& Cela, R. (2005). Application of matrix solid-phase dispersion in the analysis of priority polycyclic aromatic hydrocarbons in fish samples. Journal of Chromatography A, 1077, 103-109.

Perelló, G., Marti-Cid, R., Castell, V., Llobet, J. M., \& Domingo, J. L. (2009). Concentrations of polybrominated diphenyl ethers, hexachlorobenzene and polycyclic aromatic hydrocarbons in various foodstuffs before and after cooking. Food and Chemical Toxicology, 47, 709-715.

Portet-Koltalo, F., Oukebdane, K., Dionnet, F., \& Desbène, P. L. (2008). Optimisation of the extraction of polycyclic aromatic hydrocarbons and their nitrated derivatives from diese particulate matter using microwave-assisted extraction. Analytical and Bioanalytical Chemistry, 390, 389-398.

Ramalhosa, M. J., Paíga, P., Morais, S., Delerue-Matos, C., \& Oliveira, M. B. P. P. (2009). Analysis of polycyclic aromatic hydrocarbons in fish: Evaluation of a quick, easy, cheap, effective, rugged, and safe extraction method. Journal of Separation Science, 32, 3529-3538.

Richardi, J., \& Krienke, H. (1997). Dielectric and structural results for liquid acetonitrile, acetone and chloroform from the hypernetted chain molecular integral equation. Molecular Physics, 90, 841-853.

Sanz-Landaluze, J., Bartolome, L., Zuloaga, O., González, L., Dietz, C., \& Cámara, C. (2006) Accelerated extraction for determination of polycyclic aromatic hydrocarbons in marine biota. Analytical and Bioanalytical Chemistry, 384, 1331-1340.

Selli, S., \& Cayhan, G. G. (2009). Analysis of volatile compounds of wild gilthead sea bream (Sparus aurata) by simultaneous distillation-extraction (SDE) and GC-MS. Microchemical Journal, 93, 232-235.

Serpe, F. P., Esposito, M., Gallo, P., \& Serpe, L. (2010). Optimisation and validation of na HPLC method for determination of polycyclic aromatic hydrocarbons (PAHs) in mussels. Food Chemistry, 122, 920-925.

Soclo, H. H., Budzinski, H., Garrigues, Ph., \& Matsuzawa, S. (2008). Biota accumulation of polycyclic aromatic hydrocarbons in Benin coastal waters. Polycyclic Aromatic Compounds, 28, 112-127.

Sousa, A. M. M., Alves, V. D., Morais, S., Delerue-Matos, C., \& Gonçalves, M. P. (2010). Agar extraction from integrated multitrophic aquacultured Gracilaria vermiculophylla: Evaluation of a microwave-assisted process using response surface methodology. Bioresource Technology, 101, 3258-3267.

Stolyhwo, A., \& Sikorski, Z. E. (2005). Polycyclic aromatic hydrocarbons in smoked fish-a critical review. Food Chemistry, 91, 303-311.

U.S. Environmental Protection Agency (USEPA) (1986). Guidelines for Carcinogen Risk Assessment. Federal Register 51(185):33992-34003, EPA/630/R-00/004 U.S. Government Printing Office, Washington, DC

U.S. Environmental Protection Agency (2000). EPA Method 3546. Microwave extraction of VOCS and SVOCs organophosphorus pesticides, organochlorine pesticides, chlorinated herbicides, phenoxy acid herbicides, PCBs. Cincinnati, OH: U.S. Environmental Protection Agency, Office of Research and Development, National Exposure Research Laboratory.

Veyrand, B., Brosseaud, A., Sarcher, L., Varlet, V., Monteau, F., Marchand, P., et al. (2007) Innovative method for determination of 19 polycyclic aromatic hydrocarbons in food and oil samples using gas chromatography coupled to tandem mass spectrometry based on an isotope dilution approach. Journal of Chromatography A, 1149, 333-344.

WHO. (1998). Environmental health criteria 202: Selected non-heterocyclic polycyclic aromatic hydrocarbons. International Programme on Chemical Safety. World Health Organisation, Geneva.

Yusà, V., Pardo, O., Martí, P., \& Pastor, A. (2005). Application of accelerated solvent extraction followed by gel performance chromatography and high-performance liquid chromatography for the determination of polycyclic aromatic hydrocarbons in mussel tissue. Food Additives \& Contaminants: Part A, 22, 482-489. 